\title{
Interdependence between the stock market and the bond market in one country: evidence from the subprime crisis and the European debt crisis
}

Ke Cheng ${ }^{1 *}$ and Xiaoguang Yang ${ }^{1,2}$

\author{
* Correspondence: \\ chengke@amss.ac.cn \\ ${ }^{1}$ China University of Petroleum, \\ Beijing 102249, People's Republic of \\ China \\ Full list of author information is \\ available at the end of the article
}

\begin{abstract}
Background: Once a global financial crisis breaks out, the interdependence between different financial markets suddenly increases and leads to a significant contagion.

Methods: With 39 countries used as samples, this paper analyzes the interdependence between the stock market and the government bond market during the crisis periods.

Results: It proves that the investor focuses more on the safety of their portfolio so there is neither a flight from quality nor a positive spillover during a crisis period. When one market is safer than the other market in the same country, a flight to quality occurs between the two markets; however, when the two markets in one country are both risky, negative spillover appears between these two markets.

Conclusions: This means a flight to quality from the stock market to the short-term government bond will occur more frequently than will occur from the stock market to the long-term government bond markets. In addition, a flight to quality always emerges in developed markets, while negative spillovers take place in emerging markets and in the PIIGS countries (Portugal, Italy, Ireland, Greece, and Spain, referred to hereon as "P\|GS") in the European Debt Crisis.
\end{abstract}

\section{Background}

In the 21th century, there have been two destructive global financial crises, i.e., the Subprime Crisis in 2007-2009 and the 2009's European Debt Crisis. Once a global financial crisis breaks out, the interdependence between different financial markets suddenly increases and leads to a significant contagion.

Although most of the co-movements between the stock market and the bond market demonstrate interdependence instead of a contagion, as Forbes and Rigobon (2002) mentioned, this interdependence could be deemed an overture of financial contagion. Because interdependence occurs more frequently than contagion, which is a special type of interdependence, it is more important to examine the mechanism of interdependence during a crisis period. The stock market is the largest and most liquid market in most regions. Meanwhile, the markets of bonds, commodities and derivatives also develop quickly in many countries. In addition to the stock market, the bond market is another financial market with large trade volumes. Therefore, any

(c) The Author(s). 2017 Open Access This article is distributed under the terms of the Creative Commons Attribution 4.0 International License (http://creativecommons.org/licenses/by/4.0/), which permits unrestricted use, distribution, and reproduction in any medium, provided you give appropriate credit to the original author(s) and the source, provide a link to the Creative Commons license, and indicate if changes were made. 
interdependence between the stock market and the bond market is more important and significant than that between some other markets.

Most studies have proven the negative correlation between the stock market and the bond market in non-crisis periods. Theoretically, there are four types of interdependence between a stock market and bond market that exist in the same country. During a period of financial crisis, investors tend to transfer their investments from the risky markets to safer markets in order to avoid significant losses. This flight to quality accelerates the fund run-off from markets in crisis and amplifies the contagion effect, while it might increase the investors' utility. After the crisis, investors often rebalance their investments from safe assets (e.g. bonds) to riskier assets (for example, stocks). This rebalance is known as a flight from quality. Additionally, as another common interdependence in the financial crisis, negative spillover refers to the negative co-movement of asset prices between several financial markets in the crisis. This is because the markets might all exist in an unsafe region, so investors consequently rebalance their portfolios and investments to flow into another, safer region. This positive spillover may also occur in similar markets as an economy starts to recover and the confidence of the investors increases.

Different types of interdependence suggest different patterns of investor behavior during a period of financial crisis. As such, it is necessary to investigate different types of interdependence. Consequently, the stock market's returns generally decrease. If the correlation between the stock and the bond is negative before the crisis and becomes even more significantly negative during the crisis, this phenomenon is defined as a flight to quality, while bonds have lower risk than stocks in the same country. This suggests that investments flow from the stock market to the bond market because of higher risk aversion during a crisis. However, if the change mentioned above occurs while the return of the stock market increases, this special phenomenon is defined as a flight from quality. This phenomenon occurs during a crisis recovery period when investors seek greater risks. In addition, if the correlation between the stock and bond is negative before the crisis and becomes positive during the crisis, this phenomenon is defined as the negative spillover. This often occurs in markets that are shocked by a severe crisis and decrease all investments in different assets. Similarly, a positive spillover may happen during a crisis recovery period, which means the correlation between the stock market and the bond market becomes positive and the returns in both markets increase. The above four phenomena are defined with regard to the possibilities of relationships between the stock market and the bond market during a crisis. Most of the existing literature focuses on the flight to quality or the negative spillover, but few studies review all the four types of interdependence. However, this paper analyzes all four types of interdependence between the stock markets and the government bond markets, and their implications in two recent financial crises. In addition, the government bond markets are classified with different maturities to enrich the results. Due to the availability of the bond data, this paper focuses on the European Debt Crisis and the Subprime Crisis. For the purposes of this paper, the bankruptcy of American Home Mortgage Holdings, Inc., the 10th largest mortgage company on August 6, 2007, marks the start of the Subprime Crisis. Additionally, the European Debt Crisis began with the first degradation of Greece on October 22, 2008.

This paper also focuses on different types of interdependence between the stock markets and government bond markets in the same region. First, the interdependence between the stock markets and the bond markets in the same region is much more 
important than the interdependence across different regions (Baur and Lucey 2009). Second, the paper investigates the interdependence between the stock markets and the bond markets in 39 countries. The samples already cover approximately $80 \%$ of the global GDP, and therefore, it can be concluded that this paper's analysis is reliable. The interdependence across different regions may result in an overly complicated analysis. In addition, over recent years the interdependence between the stock markets and the bond markets has become quite valuable because the debt crisis is one of the most important parts in the Subprime Crisis and the European Debt Crisis. The financial derivatives or the real estate markets are less liquid and important than government bond markets in most of the emerging markets. Thus, in this paper, our analysis emphasizes the stock markets and the government bond markets in 39 countries.

The primary result in this paper is that there are the significant instances of flight to quality and the negative spillover in the European Debt Crisis and the Subprime Crisis. Furthermore, the interdependence between the stock markets and the bond markets in these recent crises is classified and the characteristics are summarized according to region. Compared to existing studies, our analysis is based on a rich dataset that includes the stock markets and the government bond markets in 39 countries around the world. Lastly, a general implication is provided for the characteristics of interdependence in the recent two global financial crises.

The rest of this paper is organized as follows. Section II begins with a brief review of the theory on interdependence and contagion during times of financial crisis. In Section III, the analysis methodology is investigated; additionally, our hypotheses are listed in this section. In Section IV, a brief description of the data in the analysis is provided. Next, in Section V, we present discussions about the interdependence between the stock markets and the government bond markets in 39 countries, including three subtopics. The analysis in this work proves that the interdependence between the stock markets and the government bond markets occurs in most of the 39 countries. Next, the characteristics of the interdependence in those different regions and crises are, respectively, analyzed. In Section VI, the robustness of the results is emphasized and the findings are reconciled using the same dataset. Finally, Section VII includes this work's results and consequential policy implications.

Compared to the existing literature, the latest global financial crises are currently studied using more abundant samples, i.e., 39 different countries and regions, a method that is in favor of financial contagion studies. Additionally, in the final results, conducting empirical research is successful in classifying possible types of interdependence between the stock markets and the government bond markets. Furthermore, it has been found that risk aversion frequently causes investment flows across different regions in financial crises, which is simple but convincing logic regarding the special patterns of interdependence during the Subprime Crisis and the European Debt Crisis.

\section{Literature review}

Many studies have revealed the significant interdependence between the stock markets and the bond markets in certain countries during past financial crises.

Aslanidisa and Christiansen (2012) proved the interdependence between the U.S. stock markets and bond markets by adopting the Markov-switching method proposed by Hamilton (Hamilton 1989). Furthermore, Chan et al. (2011) analyzed the contagion 
between different financial markets, including stock markets, bond markets, commodity markets and real estate markets. Additionally, interdependence evidences different correlations during different stages. Based on these findings, Gulko (2002), Baur and Lucey (2009) defined the flight to quality between the stock markets and the bond markets. Cheng et al. (2011) took the Copula Contagion Index as a method of measuring the financial contagion of 50 countries. They investigated the contagion in 13 financial crises during recent 20 years, but their studies were limited to the stock market.

These previous studies have seldom involved different types of interdependence across different asset markets in the same region. Most of the papers mentioned above focus on the interdependence between different regional markets for one identified financial asset. For instance, Brièrea et al. (2012) investigated the interdependence between different regions. They proved that the flight to quality is more frequent than the contagion during a financial crisis. The existing studies on different types of interdependence feature two limitations. First, the majority of studies focus on the logic of the flight to quality or co-movements, because cash flow direction is not published and is in reality difficult to track. Bernanke et al. (1996) analyzed the mechanism of flight to quality in the credit market by employing the general equilibrium model. Vayanos (2004) compared the flight to quality and the flight to liquidity in the different asset markets using dynamic stochastic general equilibrium modeling. Caballero and Krishnamurthy (2008) also investigated the lender of the last resort during the flight to quality period under the guidance of general equilibrium theory. Second, some studies on interdependence between different assets focus on interdependence in one specific country but seldom conduct a comparison of interdependence between various asset markets in different regions, especially the comparisons between developed and emerging markets. Lang and Nakamura (1995) summarized the rules of flight to quality in the U.S. credit markets, while Baur and Lucey (2009) focused on flight to quality in the stock markets and corporate bond markets in the G8 countries; however, they failed to study a similar phenomenon in emerging markets. Beber et al. (2009) found that interdependence is aroused by flight to liquidity instead of quality when investigating interdependence in the European government bond markets.

\section{Methods}

In this paper, the interdependence between the stock markets and the government bond markets of 39 countries is studied in three steps.

Firstly, using the Markov-switching method, this work tests whether the interdependence between the stock markets and the government bond markets occurred during the Subprime Crisis and the European Debt Crisis. A sudden increase in correlations during the crises would prove significant interdependence between the stock markets and the government bond markets. Secondly, this work clarifies all kinds of interdependence by measuring the flight to quality, the flight from quality, the negative spillover and the positive spillover in conjunction with the different changing directions of interdependence. This work also summarizes the features of interdependence between the stock markets and government bond markets in various regions. Lastly, the characteristics of the interdependence in the Subprime Crisis and the European Debt Crisis are also mentioned, respectively. 
The test for interdependence between the stock markets and the government bond markets in the same country

Based on the Markov-switching method, we tested the correlation between the stock markets and the short-term and long-term government bond markets in the same country to investigate whether the interdependence exists during the Subprime Crisis and the European Debt Crisis. Actually, the Markov-switching method is similar to the Markov-switching regression proposed by Hamilton (1989):

$$
\begin{aligned}
& \mathrm{R}_{\mathrm{i}, \mathrm{t}}^{S}=c_{i}+\beta_{i}^{S} \mathrm{R}_{\mathrm{i}, \mathrm{t}-1}^{\mathrm{S}}+\beta_{i}^{s B} \mathrm{R}_{\mathrm{i}, \mathrm{t}}^{\mathrm{sB}}+\beta_{i}^{l B} \mathrm{R}_{\mathrm{i}, \mathrm{t}}^{\mathrm{lB}}+\epsilon_{i},{ }_{t}, \epsilon_{i}, t^{\sim N}\left(0, \sigma_{i}^{2}\right), \\
& \mathrm{p}_{\mathrm{i}, \mathrm{j}}=\operatorname{Prob}\left(s_{t}=j \mid s_{t-1}=i\right), p_{i 1}+p_{i 2}=1, i=1,2
\end{aligned}
$$

In Formula (1), the dependent variable is $\mathrm{R}_{i, t}^{S}$, i.e., the return of the stock market. To study the dependence and enrich the results, the returns of short-term and long-term government bonds (i.e., $\mathrm{R}_{i, t}^{s B}$ and $\mathrm{R}_{i, t}^{l B}$, respectively) are introduced into Formula (1) to test their correlations with the stock market in the same country. In order to take the momentum effect into account, the 1-period (i.e., 1-month) lag return $\mathrm{R}_{i, t-1}^{S}$ of the stock market is considered an independent variable.

All the independent and dependent variables have two transition statuses in Formula (1). The transition status can be defined as the non-crisis status that refers to the status with a higher volatility of returns and the crisis status, which is related to the lower volatility of returns.

If the estimation of the bond coefficients is significant enough in Formula (1), it can be proved that some interdependence exists between the stock markets and the related bond markets. Therefore, the implication of the interdependence can be analyzed by verifying its direction in the following sections.

\section{The investigation of different types of interdependence}

The interdependence in this paper is defined as the significant increase in the correlation between the two markets. Based on the direction of the correlations as well as Baur and Lucey (2009)'s analysis, there are four types of interdependence, as follows (Table 1).

Different types of the interdependence are measured through the regressions using crisis dummy variables. Similar to Formula (1), the return of the stock market is a dependent variable, while the returns of the short-term and the long-term government bond markets are independent variables in Formula (2). To decrease the autocorrelation, the lag item of the stock return is introduced into Formula (2).

\begin{tabular}{|c|c|c|c|c|c|}
\hline \multirow[t]{2}{*}{ Returns } & \multirow[t]{2}{*}{ Change } & \multicolumn{2}{|c|}{ Short-term (1-3 year) government bond } & \multicolumn{2}{|c|}{ Long-term (7-10 year) government bond } \\
\hline & & $\begin{array}{l}\text { Negative Correlation } \\
\text { \& Negative Changing } \\
\text { Direction }\end{array}$ & $\begin{array}{l}\text { Positive Correlation } \\
\text { \& Positive Changing } \\
\text { Direction }\end{array}$ & $\begin{array}{l}\text { Negative Correlation } \\
\& \text { Negative Changing } \\
\text { Direction }\end{array}$ & $\begin{array}{l}\text { Positive Correlation } \\
\text { \& Positive Changing } \\
\text { Direction }\end{array}$ \\
\hline \multirow[t]{2}{*}{$\begin{array}{l}\text { Stock } \\
\text { Market }\end{array}$} & Downside & $\begin{array}{l}\text { Flight to Quality } \\
\text { (FTQ) }\end{array}$ & $\begin{array}{l}\text { Negative Spillover } \\
\text { (NS) }\end{array}$ & $\begin{array}{l}\text { Flight to Quality } \\
\text { (FTQ) }\end{array}$ & $\begin{array}{l}\text { Negative Spillover } \\
\text { (NS) }\end{array}$ \\
\hline & Upside & $\begin{array}{l}\text { Flight from Quality } \\
\text { (FFQ) }\end{array}$ & $\begin{array}{l}\text { Positive Spillover } \\
\text { (PS) }\end{array}$ & $\begin{array}{l}\text { Flight from Quality } \\
\text { (FFQ) }\end{array}$ & $\begin{array}{l}\text { Positive Spillover } \\
\text { (PS) }\end{array}$ \\
\hline
\end{tabular}

Table 1 Possible interdependences between the stock and the government bond markets 


$$
\mathrm{R}_{\mathrm{t}}^{\mathrm{S}}=c_{t}+\beta^{S} \mathrm{R}_{\mathrm{t}-1}^{\mathrm{S}}+\beta^{s B} \mathrm{R}_{\mathrm{t}}^{\mathrm{sB}}+\beta^{l B} \mathrm{R}_{\mathrm{t}}^{\mathrm{lB}}+\gamma^{s B} R_{t}^{s B} D_{t}^{\text {Crisis }}+\gamma^{l B} R_{t}^{l B} D_{t}^{\text {Crisis }}+\epsilon_{t}, \epsilon_{t} \sim N\left(0, \sigma_{i}^{2}\right)
$$

In Formula (2), $\mathrm{R}_{t}^{S}, \mathrm{R}_{t}^{l B}$ and $\mathrm{R}_{t}^{s B}$ refer to the returns of the stock market, the long-term government bond market and the short-term government bond market at Period $\mathrm{t}$, respectively. $D_{t}^{\text {Crisis }}$ refers to the crisis dummy variable. As the lag item of the stock return is incorporated, the error follows the normal distribution and passes the DW test. Then, types of interdependences can be tested through the coefficients $\beta$ and $\gamma$.

Furthermore, in order to compare different types of interdependence during the two crises in recent years, different dummy variables are considered in the European Debt Crisis and the U.S. subprime mortgage crisis on the basis of Formula (2).

$$
\begin{aligned}
\mathrm{R}_{\mathrm{t}}^{\mathrm{S}}=c_{t}+\beta^{S} \mathrm{R}_{\mathrm{t}-1}^{\mathrm{S}} & +\beta^{s B} \mathrm{R}_{\mathrm{t}}^{\mathrm{sB}}+\beta^{l B} \mathrm{R}_{\mathrm{t}}^{\mathrm{IB}}+\gamma^{s B} R_{t}^{s B} D_{t}^{\text {Crisis } 1}+\gamma^{l B} R_{t}^{l B} D_{t}^{\text {Crisis } 1}+\mu^{\mathrm{sB}} \mathrm{R}_{\mathrm{t}}^{\mathrm{sB}} D_{t}^{\text {Crisis } 2} \\
& +\mu^{1 \mathrm{~B}} \mathrm{R}_{\mathrm{t}}^{1 \mathrm{~B}} D_{t}^{\text {Crisis } 2}+\epsilon_{t}, \epsilon_{t} \sim N\left(0, \sigma_{i}^{2}\right)
\end{aligned}
$$

\section{Hypotheses}

Based on the above definitions, several hypotheses are proposed for the following analysis.

Hypothesis 1 The interdependence becomes more significant once the crisis breaks out.

Hypothesis 2 There is neither a flight from quality nor a positive spillover during the periods of the Subprime Crisis and the European Debt Crisis.

The two hypotheses mentioned above are somewhat trivial. To begin with, when the financial crisis occurs, most investors will rebalance their portfolio to reduce any risk to their investments. Considering that a great number of investors take different positions in different financial markets, this should increase the interdependence across financial markets. Furthermore, the definitions of the flight from quality and the positive spillover need the increasing return of the stock markets. Because the stock market is the most vulnerable financial market in most countries, any increase of the stock return is nearly impossible during a crisis period.

Hypothesis 3 Compared to the long-term government bond market, the flight to quality between the stock markets and the short-term government bond markets is more significant.

In comparison to the short-term government bonds, the performance of the long-term government bonds relies more on the long-term economic trend of the related countries rather than the investor's emotion. However, the flight to quality is often a short-term phenomenon and depends more on the investors' emotion during the crisis period. Considering that the sovereign debt of the related countries might increase markedly, the probability of default will also be much higher for the long-term government bonds. In this situation, the long-term government bonds cannot be deemed as safe financial assets. Therefore, it is mentioned in Hypothesis 3 that the fight-to-quality is more dramatic between the stock markets and the short-term government bond markets. 
Hypothesis 4 In regards to interdependence between the stock markets and the government bond markets in the same country, the flight to quality often occurs in developed markets while the negative spillover often appears in the emerging markets.

It is obvious that the emerging markets are more vulnerable than the developed markets because emerging countries sometimes have an unstable political system, especially during the crisis. That is why government bonds in emerging countries are considered an unsafe asset in a financial crisis. In addition, those government bonds will not attract international investors due to greater political risk. In this case, most investors choose to turn away from the emerging markets instead of changing their stock position to the bond position. Thus, the negative spillover emerges more frequently than the flight to quality in the emerging markets.

Hypothesis 5 The countries where the flight to quality happens become less frequent in the European Debt Crisis than in the U.S. subprime mortgage crisis.

Similar to Hypothesis 4, the number of countries that suffered from the sovereign debt crisis increased during the European Debt Crisis. Furthermore, as the European Debt Crisis is regarded to be a sovereign debt crisis and also the sequel of the Subprime Crisis, there are fewer government bond markets of high quality. Therefore, government bonds cannot be treated as quality assets and the flight to quality also became less frequent during the European Debt Crisis.

Data

\section{Government bonds}

There are many kinds of government bonds in the financial markets. In addition, shortterm and long-term government bonds often perform differently in different countries. Therefore, choosing the proper government bonds is a key question in the study.

All the government bonds in this paper were chosen as the bond indices from the Bloomberg database. Based on the maturity of the bonds, the 7-10 year government bond index was selected as the proxy for the long-term government bonds, while the 1-3 year government bond index was chosen as the proxy for the short-term government bonds (Table 2). Then, all the countries that have reliable government bond indices in Bloomberg were selected. In terms of geographic location, the samples involve 39 countries on six continents, i.e. Europe, Asia, North America, Latin America, and Oceania. Economically speaking, these 39 countries can be divided into developed markets, and those emerging markets take up more than $75 \%$ of the global GDP.

All the government bond indices in these 39 countries can be classified into 4 types, according to their data source. Firstly, the government bond indices in most developed markets are the EFFA Government Bond Indices, which are calculated by value weights and the liquidity consideration of Bloomberg. Their value reflects the value-weighted clean prices of most liquid government bonds with the related maturity. The second type of index is the inflation-adjusted government bond index for Latin American countries. This index was chosen for Latin American countries because of the high inflation in those countries. Therefore, the inflation-adjusted government bonds are more popular and liquid in Latin America. There are no EFFA Government Bond Indices for certain Southeast Asian countries or regions in the Bloomberg database. In this case, 
Table $\mathbf{2}$ List of the stock and government bond indices

\begin{tabular}{|c|c|c|c|}
\hline Country & Type of Market & Government Bond Index & Stock Index \\
\hline Argentina & Emerging America & Inflation-Adjusted & MERV \\
\hline Australia & Developed Asia & EFFA & S\&P 200 \\
\hline Austria & Developed Europe & EFFA & AUX \\
\hline Belgium & Developed Europe & EFFA & $\mathrm{BFX}$ \\
\hline Brazil & Emerging America & Inflation-Adjusted & IBOVESPA \\
\hline Canada & Developed America & EFFA & Toronto 300 \\
\hline Chile & Emerging America & Inflation-Adjusted & IPSA \\
\hline China & Emerging Asia & Zhongzhai All-value & Shanghai Composite \\
\hline Czech & Emerging Europe & EFFA & Prague Composite \\
\hline Denmark & Developed Europe & EFFA & OMX20 \\
\hline Finland & Developed Europe & EFFA & OMX \\
\hline France & Developed Europe & EFFA & CAC40 \\
\hline Germany & Developed Europe & EFFA & DAC \\
\hline Greece & Developed Europe & EFFA & ASE Composite \\
\hline Hungary & Emerging Europe & EFFA & $B \cup X$ \\
\hline India & Emerging Asia & Value-weighted Yield & SENSEX30 \\
\hline Indonesia & Emerging Asia & Value-weighted Yield & Jakarta Composite \\
\hline Ireland & Developed Europe & EFFA & Ireland Composite \\
\hline Israel & Developed Asia & Inflation-Adjusted & TA100 \\
\hline Italy & Developed Europe & EFFA & FTSEMIB \\
\hline Japan & Developed Asia & EFFA & Nikkei 225 \\
\hline Korea & Developed Asia & EFFA & Korea Composite \\
\hline Mexico & Emerging America & Inflation-Adjusted & $M X X$ \\
\hline Netherlands & Developed Europe & EFFA & AEX \\
\hline New Zealand & Developed Asia & EFFA & NZ50 \\
\hline Norway & Developed Europe & EFFA & OSEAX \\
\hline Poland & Emerging Europe & EFFA & WIG20 \\
\hline Portugal & Developed Europe & EFFA & PSI20 \\
\hline Russia & Emerging Europe & Exposure-weighted Price & RTS \\
\hline South Africa & Emerging Asia & EFFA & JALSH \\
\hline Spain & Developed Europe & EFFA & IBEX35 \\
\hline Sweden & Developed Europe & EFFA & OMXSPI \\
\hline Switzerland & Developed Europe & EFFA & SMI \\
\hline Taiwan & Emerging Asia & Value-weighted Yield & Taiwan Value-added \\
\hline Thailand & Emerging Asia & Value-weighted Yield & Thailand Composite \\
\hline Turkey & Emerging Europe & Inflation-Adjusted & Istanbul 30 \\
\hline UK & Developed Europe & EFFA & FTSE 100 \\
\hline US & Developed America & EFFA & S\&P 500 \\
\hline Vietnam & Emerging Asia & Value-weighted Yield & VNINDEX \\
\hline
\end{tabular}

we chose the value-weighted return of the government bonds and generated the clean price indices for these countries. Finally, there are no reliable government bond indices for Russia and Mainland China in the above three categories. Thus, we have taken into 
consideration the exposure-weighted government bond index for Russia and Zhongzhai All-value Government Bond Index for China, respectively.

The above government bond indices in the recent 10 years and 39 countries were collected. The time range is from October 2002 to June 2012. To eliminate the asynchronous effect and maintain the maximal information, the weekly returns were generated with the weekly bond indices using the logarithm function, i.e. the log (the close price in the end of this week/the close price in the end of last week).

\section{Stocks}

As for the stock market, the value-weighted indices produced by most liquid stocks were used as the proxy, since more than half of the sample countries are emerging markets with a number of illiquid stocks, which do not accurately reflect the prosperity of the stock market.

To compare the stock data with the bond data in the model, a similar method was adopted to generate the weekly log-return from October 2002 to June 2012. This period is the longest available period from the Wind database and the Bloomberg database.

\section{Results and discussion}

Investors always hold several kinds of financial positions as a portfolio to diversify their risk in the financial markets. Rebalancing their portfolio often leads to interdependence between different financial markets once a financial crisis breaks out. Thus, in this section, various types of interdependence between the stock markets and the government bond markets in the listed 39 countries were analyzed by adopting the methods mentioned in Section III.

\section{The existence of interdependence}

The analysis concerning interdependence between the stock markets and the government bond markets in 39 countries is made through the 39 independent Markov Switching regressions as Formula (1). All the estimations are summarized in Table 3. The estimations in the 39 regressions are statistically significant because most of their P-values are lower than $10 \%$ and their AIC statistics are significant enough. In addition, the coefficients of the lag item of the stock market return are much more positive during a non-crisis status than during a crisis status for the majority of regressions. It is shown that, for most stock markets, the momentum effects become less significant and the stock returns influence the bond markets more easily in crisis periods.

As Krolzig (2004) proved that the market returns are more volatile during the crisis period, the crisis status is defined as switching status with one more volatile (i.e., Status 1 in Table 4) in this paper. The intercepts refer to the mean value of the stock market return, excluding the lag effect and the bond market effect in different switching statuses. In a crisis status defined in terms of volatility, the mean value of the stock market returns is lower for most of the regressions except for those in Mainland China, Russia and Vietnam. This also proves that in this paper, the definition of the crisis status is appropriate.

Moreover, this formula is analyzed in Hypothesis 1 in Section III. In most of the regressions, the coefficients of the long-term bonds have smaller absolute values than the coefficients of short-term bonds. When compared with the short-term government bonds, the long-term bonds have less of an effect on the stock market in the same country Table 5 . 
Table 3 Detailed results of markov switching regressions

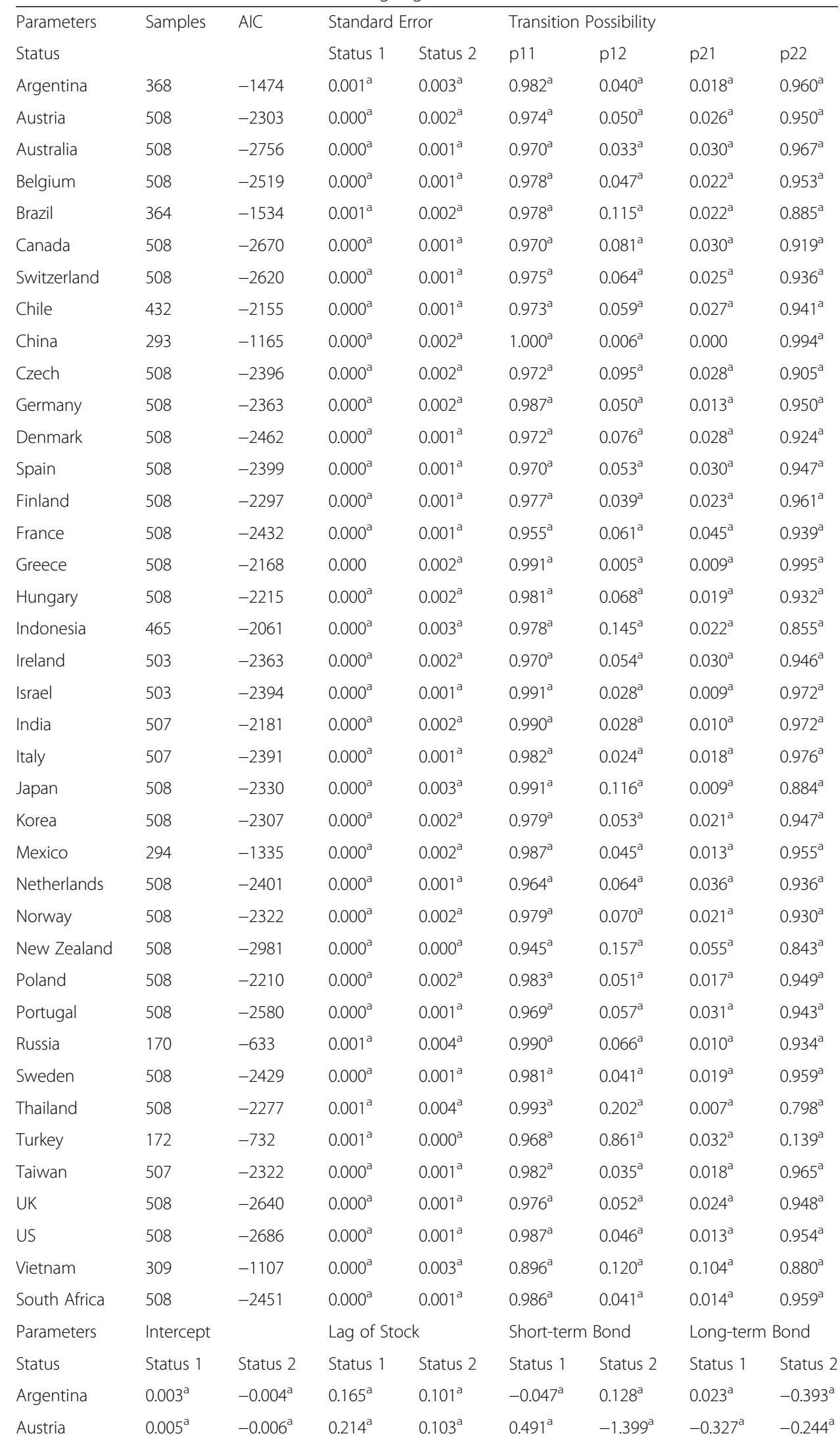


Table 3 Detailed results of markov switching regressions (Continued)

\begin{tabular}{|c|c|c|c|c|c|c|c|c|}
\hline$\overline{\text { Australia }}$ & $0.003^{a}$ & $-0.001^{\mathrm{a}}$ & $0.261^{\mathrm{a}}$ & $0.006^{\mathrm{a}}$ & $0.015^{a}$ & $-1.638^{\mathrm{a}}$ & $0.028^{a}$ & $-0.183^{a}$ \\
\hline Belgium & $0.003^{a}$ & $-0.003^{\mathrm{a}}$ & $0.190^{\mathrm{a}}$ & $0.166^{a}$ & $0.359^{a}$ & $-1.125^{\mathrm{a}}$ & $-0.165^{\mathrm{a}}$ & $-0.025^{\mathrm{a}}$ \\
\hline Brazil & $0.002^{\mathrm{a}}$ & $-0.015^{\mathrm{a}}$ & $0.196^{\mathrm{a}}$ & $-0.138^{\mathrm{a}}$ & $0.819^{a}$ & $1.187^{\mathrm{a}}$ & $0.025^{a}$ & $0.631^{\mathrm{a}}$ \\
\hline Canada & $0.003^{\mathrm{a}}$ & $-0.001^{a}$ & $0.109^{a}$ & $0.060^{a}$ & $-0.172^{\mathrm{a}}$ & $-2.359^{a}$ & $0.012^{a}$ & $-0.205^{a}$ \\
\hline Switzerland & $0.003^{\mathrm{a}}$ & $-0.005^{\mathrm{a}}$ & $0.114^{\mathrm{a}}$ & $-0.080^{\mathrm{a}}$ & $0.410^{a}$ & $-1.767^{\mathrm{a}}$ & $-0.171^{\mathrm{a}}$ & $0.044^{a}$ \\
\hline Chile & $0.004^{a}$ & $-0.003^{a}$ & $0.192^{\mathrm{a}}$ & $0.100^{a}$ & $0.204^{a}$ & $-0.577^{\mathrm{a}}$ & $0.028^{a}$ & $-0.062^{\mathrm{a}}$ \\
\hline China & $-0.002^{a}$ & $0.002^{a}$ & $0.146^{a}$ & $0.199^{a}$ & $3.415^{a}$ & $-0.809^{a}$ & $-2.131^{\mathrm{a}}$ & $-0.743^{\mathrm{a}}$ \\
\hline Czech & $0.004^{\mathrm{a}}$ & $-0.006^{\mathrm{a}}$ & $0.246^{\mathrm{a}}$ & $0.206^{\mathrm{a}}$ & $0.219^{a}$ & $-2.789^{a}$ & $-0.191^{a}$ & $0.120^{\mathrm{a}}$ \\
\hline Germany & $0.003^{\mathrm{a}}$ & $0.001^{\mathrm{a}}$ & $0.093^{\mathrm{a}}$ & $-0.011^{\mathrm{a}}$ & $0.339^{a}$ & $-2.758^{\mathrm{a}}$ & $-0.308^{\mathrm{a}}$ & $-0.149^{\mathrm{a}}$ \\
\hline Denmark & $0.004^{a}$ & $0.000^{\mathrm{a}}$ & $0.111^{a}$ & $0.108^{a}$ & $0.410^{a}$ & $-3.466^{\mathrm{a}}$ & $-0.206^{\mathrm{a}}$ & $0.045^{a}$ \\
\hline Spain & $0.002^{a}$ & $-0.004^{a}$ & $0.215^{a}$ & $0.055^{a}$ & $0.308^{a}$ & $0.171^{a}$ & $0.011^{a}$ & $0.117^{\mathrm{a}}$ \\
\hline Finland & $0.003^{a}$ & $-0.004^{a}$ & $0.216^{a}$ & $0.092^{a}$ & $0.633^{a}$ & $0.342^{a}$ & $-0.532^{\mathrm{a}}$ & $-0.539^{a}$ \\
\hline France & $0.003^{\mathrm{a}}$ & $-0.003^{\mathrm{a}}$ & $0.132^{a}$ & $0.013^{a}$ & $0.589^{a}$ & $0.081^{a}$ & $-0.251^{a}$ & $-0.362^{a}$ \\
\hline Greece & $0.003^{a}$ & -0.007 & 0.241 & $0.212^{a}$ & 0.899 & $-0.151^{\mathrm{a}}$ & $-0.396^{a}$ & $0.197^{a}$ \\
\hline Hungary & $0.003^{a}$ & $-0.009^{\mathrm{a}}$ & $0.208^{a}$ & $0.062^{a}$ & $-0.117^{a}$ & $3.166^{a}$ & $0.232^{a}$ & $-0.497^{a}$ \\
\hline Indonesia & $0.007^{\mathrm{a}}$ & $-0.020^{a}$ & $0.153^{\mathrm{a}}$ & $-0.258^{a}$ & $-0.002^{a}$ & $0.022^{a}$ & $-0.080^{\mathrm{a}}$ & $-0.464^{\mathrm{a}}$ \\
\hline Ireland & $0.004^{a}$ & $-0.008^{a}$ & $0.165^{\mathrm{a}}$ & $0.135^{a}$ & $0.034^{a}$ & $0.304^{a}$ & $0.039^{a}$ & $-0.436^{\mathrm{a}}$ \\
\hline Israel & $0.003^{a}$ & $-0.002^{a}$ & $0.151^{a}$ & $0.141^{a}$ & $-0.171^{\mathrm{a}}$ & $0.713^{a}$ & $0.184^{a}$ & $-0.170^{a}$ \\
\hline India & $0.004^{\mathrm{a}}$ & $-0.002^{a}$ & $0.251^{a}$ & $0.109^{a}$ & $0.042^{a}$ & $0.072^{a}$ & $-0.056^{a}$ & $-0.246^{a}$ \\
\hline Italy & $0.001^{a}$ & $-0.004^{\mathrm{a}}$ & $0.218^{\mathrm{a}}$ & $0.127^{\mathrm{a}}$ & $1.021^{\mathrm{a}}$ & $-0.961^{\mathrm{a}}$ & $-0.009^{\mathrm{a}}$ & $0.226^{a}$ \\
\hline Japan & $0.001^{a}$ & $-0.011^{a}$ & $0.097^{\mathrm{a}}$ & $0.070^{a}$ & $1.004^{\mathrm{a}}$ & $-1.676^{\mathrm{a}}$ & $-0.787^{\mathrm{a}}$ & $1.407^{\mathrm{a}}$ \\
\hline Korea & $0.005^{\mathrm{a}}$ & $-0.005^{\mathrm{a}}$ & $0.143^{\mathrm{a}}$ & $0.156^{a}$ & $-0.303^{a}$ & $-1.576^{\mathrm{a}}$ & $-0.070^{a}$ & $1.348^{a}$ \\
\hline Mexico & $0.002^{\mathrm{a}}$ & $0.000^{\mathrm{a}}$ & $0.167^{\mathrm{a}}$ & $0.026^{a}$ & $0.474^{\mathrm{a}}$ & $-0.635^{\mathrm{a}}$ & $-0.018^{a}$ & $0.210^{a}$ \\
\hline Netherlands & $0.002^{\mathrm{a}}$ & $0.001^{a}$ & $0.214^{a}$ & $0.022^{a}$ & $0.631^{a}$ & $-4.025^{\mathrm{a}}$ & $-0.268^{a}$ & $-0.116^{a}$ \\
\hline Norway & $0.006^{a}$ & $-0.007^{\mathrm{a}}$ & $0.227^{\mathrm{a}}$ & $0.030^{a}$ & $-0.874^{\mathrm{a}}$ & $-1.047^{\mathrm{a}}$ & $-0.045^{\mathrm{a}}$ & $-0.041^{a}$ \\
\hline New Zealand & $0.002^{\mathrm{a}}$ & $-0.003^{\mathrm{a}}$ & $0.288^{a}$ & $0.206^{\mathrm{a}}$ & $0.179^{a}$ & $0.910^{a}$ & $0.022^{a}$ & $-0.501^{a}$ \\
\hline Poland & $0.002^{\mathrm{a}}$ & $-0.001^{a}$ & $0.166^{\mathrm{a}}$ & $0.084^{\mathrm{a}}$ & $0.906^{\mathrm{a}}$ & $-2.034^{\mathrm{a}}$ & $-0.049^{a}$ & $0.907^{\mathrm{a}}$ \\
\hline Portugal & $0.003^{a}$ & $-0.007^{a}$ & $0.244^{a}$ & $0.108^{a}$ & $0.438^{a}$ & $0.074^{a}$ & $0.140^{\mathrm{a}}$ & $-0.183^{a}$ \\
\hline Russia & $0.000^{\mathrm{a}}$ & $0.004^{\mathrm{a}}$ & $0.186^{a}$ & $0.192^{a}$ & $1.753^{\mathrm{a}}$ & $-0.353^{\mathrm{a}}$ & $0.923^{a}$ & $0.518^{\mathrm{a}}$ \\
\hline Sweden & $0.004^{\mathrm{a}}$ & $-0.002^{a}$ & $0.090^{\mathrm{a}}$ & $0.009^{a}$ & $0.015^{\mathrm{a}}$ & $0.091^{\mathrm{a}}$ & $-0.239^{a}$ & $-0.432^{a}$ \\
\hline Thailand & $0.003^{\mathrm{a}}$ & $-0.041^{a}$ & $0.206^{\mathrm{a}}$ & $-0.265^{\mathrm{a}}$ & $-0.041^{\mathrm{a}}$ & $0.594^{\mathrm{a}}$ & $-0.028^{\mathrm{a}}$ & $-0.150^{a}$ \\
\hline Turkey & $0.005^{\mathrm{a}}$ & $-0.055^{\mathrm{a}}$ & $0.056^{\mathrm{a}}$ & $2.663^{a}$ & $0.772^{a}$ & $-1.889^{\mathrm{a}}$ & $0.261^{a}$ & $3.885^{\mathrm{a}}$ \\
\hline Taiwan & $0.003^{a}$ & $-0.003^{a}$ & $0.170^{a}$ & $0.088^{\mathrm{a}}$ & $-0.002^{\mathrm{a}}$ & $-0.031^{\mathrm{a}}$ & $0.029^{a}$ & $0.163^{\mathrm{a}}$ \\
\hline UK & $0.002^{a}$ & $-0.002^{a}$ & $0.179^{a}$ & $0.055^{a}$ & $0.405^{a}$ & $-0.418^{a}$ & $-0.086^{a}$ & $-0.128^{a}$ \\
\hline US & $0.003^{\mathrm{a}}$ & $0.002^{a}$ & $0.150^{\mathrm{a}}$ & $0.022^{a}$ & $-0.439^{a}$ & $-6.529^{a}$ & $-0.048^{a}$ & $-0.094^{a}$ \\
\hline Vietnam & $-0.003^{a}$ & $0.005^{a}$ & $0.276^{a}$ & $0.333^{a}$ & $-0.182^{a}$ & $0.247^{\mathrm{a}}$ & $-0.077^{\mathrm{a}}$ & $-0.221^{a}$ \\
\hline South Africa & $0.004^{a}$ & $-0.007^{a}$ & $0.155^{a}$ & $0.015^{a}$ & $-0.120^{a}$ & $1.894^{a}$ & $0.207^{a}$ & $-0.182^{a}$ \\
\hline
\end{tabular}

$\bar{a}$ means significance with $10 \%$ confidential interval

To begin with, the coefficients of short-term government bonds are positive during noncrisis periods, while become significantly more negative during the crisis period for most regressions. This change is especially significant in regressions for developed countries. Even for those regressions, the coefficients of short-term government bonds remain positive, while the coefficients of short-term government bonds are also somewhat smaller than the related coefficients during the non-crisis period, which means the 
Table 4 Bond coefficients in markov switching regressions

\begin{tabular}{|c|c|c|c|c|c|c|c|c|}
\hline \multirow{2}{*}{$\begin{array}{l}\text { Short-term Bonds } \\
\text { Regions }\end{array}$} & \multicolumn{4}{|c|}{ Non-Crisis } & \multicolumn{4}{|l|}{ Crisis } \\
\hline & Mean & Median & $\begin{array}{l}\text { Standard } \\
\text { Error }\end{array}$ & $\begin{array}{l}\text { Negative } \\
\text { Coefficient }\end{array}$ & Mean & Median & $\begin{array}{l}\text { Standard } \\
\text { Error }\end{array}$ & $\begin{array}{l}\text { Negative } \\
\text { Coefficient }\end{array}$ \\
\hline Developed America & -0.31 & -0.31 & 0.19 & $100 \%$ & -4.44 & -4.44 & 2.95 & $100 \%$ \\
\hline Developed Europe & 0.38 & 0.41 & 0.42 & $6 \%$ & -1.00 & -0.69 & 1.38 & $63 \%$ \\
\hline Developed Asia & 0.14 & 0.01 & 0.51 & $40 \%$ & -0.65 & -1.58 & 1.34 & $60 \%$ \\
\hline Emerging America & 0.36 & 0.34 & 0.37 & $25 \%$ & 0.03 & -0.22 & 0.85 & $50 \%$ \\
\hline Emerging Europe & 0.71 & 0.77 & 0.72 & $20 \%$ & -0.78 & -1.89 & 2.38 & $80 \%$ \\
\hline Emerging Asia & 0.44 & -0.00 & 1.31 & $71 \%$ & 0.28 & 0.07 & 0.83 & $29 \%$ \\
\hline Developed Market & 0.27 & 0.36 & 0.46 & $22 \%$ & -1.23 & -1.05 & 1.75 & $65 \%$ \\
\hline Emerging Markets & 0.51 & 0.12 & 0.93 & $44 \%$ & -0.11 & -0.00 & 1.47 & $50 \%$ \\
\hline All & 0.37 & 0.31 & 0.70 & $31 \%$ & -0.77 & -0.42 & 1.71 & $59 \%$ \\
\hline Long-term Bonds & \multicolumn{4}{|c|}{ Non-Crisis } & \multicolumn{4}{|l|}{ Crisis } \\
\hline Regions & Mean & Median & $\begin{array}{l}\text { Standard } \\
\text { Error }\end{array}$ & $\begin{array}{l}\text { Negative } \\
\text { Coefficient }\end{array}$ & Mean & Median & $\begin{array}{l}\text { Standard } \\
\text { Error }\end{array}$ & $\begin{array}{l}\text { Negative } \\
\text { Coefficient }\end{array}$ \\
\hline Developed America & -0.02 & -0.02 & 0.04 & $50 \%$ & -0.15 & -0.15 & 0.08 & $100 \%$ \\
\hline Developed Europe & -0.18 & -0.19 & 0.18 & $81 \%$ & -0.13 & -0.12 & 0.23 & $69 \%$ \\
\hline Developed Asia & -0.12 & 0.02 & 0.38 & $40 \%$ & 0.38 & -0.17 & 0.92 & $60 \%$ \\
\hline Emerging America & 0.01 & 0.02 & 0.02 & $25 \%$ & 0.10 & 0.07 & 0.43 & $50 \%$ \\
\hline Emerging Europe & 0.24 & 0.23 & 0.43 & $40 \%$ & 0.99 & 0.52 & 1.70 & $20 \%$ \\
\hline Emerging Asia & -0.31 & -0.06 & 0.81 & $71 \%$ & -0.26 & -0.22 & 0.28 & $86 \%$ \\
\hline Developed Market & -0.15 & -0.09 & 0.22 & $70 \%$ & -0.02 & -0.13 & 0.49 & $70 \%$ \\
\hline Emerging Markets & -0.06 & 0.00 & 0.61 & $50 \%$ & 0.22 & -0.11 & 1.07 & $56 \%$ \\
\hline All & -0.11 & -0.05 & 0.42 & $62 \%$ & 0.08 & -0.13 & 0.78 & $64 \%$ \\
\hline
\end{tabular}

interdependence between the stock markets and the short-term government bond markets become negative or less positive during the crisis period, though they are positive during the non-crisis period. This suggests that more investments flow from the stock markets to the short-term government bond markets during a financial crisis due to the higher quality of short-term government bonds when compared to those of stocks in the same country.

Furthermore, no matter whether a crisis period or non-crisis period is in progress, the coefficients of long-term government bonds remain negative in most regressions, which shows that investment in long-term government bonds is strongly related to the prosperity of both the local economy and financial markets. During financial crisis periods, the interdependence between the stock markets and long-term government bond markets is still similar to the interdependence in the non-crisis periods. The interdependence between the stock markets and the long-term government bond markets is often negative due to different risk patterns.

Therefore, it is possible for the interdependence between the stock market, and the shortterm and long-term government bond markets to be much higher during crisis periods than during non-crisis periods, which Hypothesis 1 already proves. In addition, it is necessary to look into different types of interdependence and determine their implications.

Different types of interdependence in the developed markets and the emerging markets In this section, the author models different types of interdependence between the stock markets and the government bond markets during the crisis period using Formula (2). 
Table 5 Detailed results of formula 2

\begin{tabular}{|c|c|c|c|c|c|c|c|c|c|c|}
\hline Country & $\begin{array}{l}\text { Adjusted } \\
\text { R-Square }\end{array}$ & F Stat & $\begin{array}{l}\text { DW } \\
\text { Stat }\end{array}$ & VIF & Intercept & $\begin{array}{l}\text { Lag of } \\
\text { Stock }\end{array}$ & $\begin{array}{l}\text { Short-term } \\
\text { Bond }\end{array}$ & $\begin{array}{l}\text { Long-Term } \\
\text { Bond }\end{array}$ & $\begin{array}{l}\text { Short-term } \\
\text { Bond }^{\mathrm{a}} \text { Crisis } \\
\text { Dummy }\end{array}$ & $\begin{array}{l}\text { Long-Term } \\
\text { Bond }^{\mathrm{a}} \text { Crisis } \\
\text { Dummy }\end{array}$ \\
\hline Argentina & 0.10 & $9.16^{\mathrm{b}}$ & 1.92 & 9.73 & 0.00 & $0.13^{\mathrm{a}}$ & $-0.12^{\mathrm{a}}$ & 0.07 & $0.21^{b}$ & $-0.34^{b}$ \\
\hline Austria & 0.05 & $6.37^{\mathrm{b}}$ & 2.00 & 6.34 & 0.00 & $0.16^{b}$ & 0.41 & -0.13 & -1.72 & -0.19 \\
\hline Australia & 0.09 & $10.59^{b}$ & 1.98 & 6.75 & $0.00^{\mathrm{a}}$ & 0.07 & 0.06 & -0.11 & $-2.37^{b}$ & 0.13 \\
\hline Belgium & 0.04 & $5.61^{b}$ & 2.00 & 7.60 & 0.00 & $0.19^{b}$ & -0.13 & -0.21 & -0.74 & 0.18 \\
\hline Brazil & 0.05 & $4.56^{\mathrm{b}}$ & 1.97 & 6.18 & 0.00 & $0.09^{\mathrm{a}}$ & $3.01^{b}$ & 0.04 & $-2.64^{\mathrm{a}}$ & 0.20 \\
\hline Canada & 0.04 & $5.43^{\mathrm{b}}$ & 1.98 & 4.90 & $0.00^{\mathrm{a}}$ & $0.10^{\mathrm{a}}$ & 0.05 & -0.02 & $-2.15^{b}$ & -0.04 \\
\hline Switzerland & 0.01 & 1.74 & 1.98 & 4.85 & 0.00 & 0.02 & -0.40 & -0.10 & -1.39 & 0.10 \\
\hline Chile & 0.02 & $2.67^{\mathrm{a}}$ & 1.98 & 5.95 & $0.00^{\mathrm{a}}$ & $0.16^{b}$ & 0.48 & 0.13 & -0.48 & -0.24 \\
\hline China & 0.07 & $5.58^{\mathrm{b}}$ & 2.03 & 14.89 & 0.00 & $0.20^{b}$ & -6.89 & -0.43 & 8.31 & -0.82 \\
\hline Czech & 0.07 & $8.79^{b}$ & 2.04 & 5.87 & 0.00 & $0.26^{\mathrm{b}}$ & 0.54 & -0.14 & $-3.84^{b}$ & 0.26 \\
\hline Germany & 0.07 & $8.77^{\mathrm{b}}$ & 2.05 & 5.59 & $0.00^{b}$ & 0.03 & 0.05 & $-0.34^{\mathrm{a}}$ & $-3.74^{b}$ & 0.26 \\
\hline Denmark & 0.05 & $6.82^{\mathrm{b}}$ & 2.03 & 7.85 & $0.00^{\mathrm{a}}$ & $0.13^{b}$ & 0.01 & -0.18 & $-2.72^{b}$ & 0.16 \\
\hline Spain & 0.02 & $2.68^{\mathrm{a}}$ & 2.01 & 8.97 & 0.00 & $0.11^{\mathrm{a}}$ & 0.93 & -0.20 & -1.11 & 0.37 \\
\hline Finland & 0.06 & $7.47^{\mathrm{b}}$ & 2.01 & 6.55 & 0.00 & $0.12^{b}$ & $1.27^{\mathrm{a}}$ & $-1.04^{b}$ & $-3.33^{b}$ & $0.78^{\mathrm{a}}$ \\
\hline France & 0.05 & $5.93^{\mathrm{b}}$ & 2.01 & 5.53 & 0.00 & 0.03 & 0.82 & -0.26 & $-3.46^{\mathrm{b}}$ & 0.10 \\
\hline Greece & 0.09 & $10.51^{b}$ & 1.99 & 34.89 & 0.00 & $0.25^{b}$ & 1.27 & -0.33 & -1.40 & $0.52^{\mathrm{a}}$ \\
\hline Hungary & 0.08 & $9.77^{b}$ & 1.96 & 10.13 & 0.00 & $0.17^{b}$ & 0.56 & 0.01 & 1.09 & -0.22 \\
\hline Indonesia & 0.05 & $5.76^{\mathrm{b}}$ & 1.98 & 5.96 & $0.00^{\mathrm{b}}$ & $0.10^{\mathrm{a}}$ & -0.02 & 0.04 & 0.03 & $-0.26^{\mathrm{a}}$ \\
\hline Ireland & 0.03 & $4.32^{\mathrm{b}}$ & 1.97 & 17.95 & 0.00 & $0.18^{b}$ & -0.23 & 0.00 & 0.41 & -0.25 \\
\hline Israel & 0.02 & $2.98^{\mathrm{a}}$ & 1.99 & 3.13 & 0.00 & $0.15^{\mathrm{b}}$ & -0.04 & 0.17 & -0.03 & -0.22 \\
\hline India & 0.03 & $4.21^{\mathrm{b}}$ & 2.00 & 6.65 & $0.00^{\mathrm{a}}$ & $0.17^{b}$ & 0.17 & -0.22 & -0.15 & 0.05 \\
\hline Italy & 0.02 & $3.33^{\mathrm{b}}$ & 1.98 & 6.97 & 0.00 & $0.14^{b}$ & -0.64 & 0.03 & -0.12 & 0.23 \\
\hline Japan & 0.04 & $4.71^{b}$ & 1.99 & 2.97 & 0.00 & $0.10^{\mathrm{a}}$ & 0.63 & $-0.49^{\mathrm{a}}$ & -2.62 & -0.08 \\
\hline Korea & 0.03 & $4.04^{\mathrm{b}}$ & 1.99 & 11.42 & 0.00 & $0.18^{\mathrm{b}}$ & -0.26 & -0.28 & -1.10 & 1.37 \\
\hline Mexico & 0.02 & $2.16^{\mathrm{a}}$ & 1.99 & 368.46 & 0.00 & 0.09 & 0.23 & 0.30 & -0.23 & -0.17 \\
\hline Netherlands & 0.08 & $10.35^{b}$ & 2.04 & 5.96 & $0.00^{\mathrm{a}}$ & 0.07 & -1.08 & -0.23 & $-3.04^{b}$ & 0.14 \\
\hline Norway & 0.04 & $4.70^{b}$ & 2.03 & 2.78 & $0.00^{\mathrm{a}}$ & $0.12^{b}$ & -0.18 & 0.06 & $-1.89^{\mathrm{a}}$ & -0.33 \\
\hline New Zealand & 0.08 & $9.22^{\mathrm{b}}$ & 1.98 & 10.65 & 0.00 & $0.28^{b}$ & 0.41 & 0.04 & -0.47 & -0.03 \\
\hline Poland & 0.03 & $3.93^{\mathrm{b}}$ & 1.99 & 4.66 & 0.00 & $0.13^{b}$ & 0.35 & 0.22 & -0.97 & 0.18 \\
\hline Portugal & 0.03 & $3.66^{\mathrm{b}}$ & 1.99 & 16.87 & 0.00 & $0.17^{b}$ & 0.87 & -0.18 & -0.85 & 0.13 \\
\hline Russia & 0.06 & $32.80^{b}$ & 2.23 & 900.75 & 0.00 & -0.01 & -0.01 & 0.09 & 0.11 & -0.11 \\
\hline Sweden & 0.04 & $4.95^{\mathrm{b}}$ & 2.02 & 6.68 & $0.00^{\mathrm{a}}$ & 0.04 & 0.28 & -0.37 & $-3.01^{\mathrm{a}}$ & 0.26 \\
\hline Thailand & 0.03 & $4.00^{\mathrm{b}}$ & 2.03 & 4.46 & $0.00^{\mathrm{a}}$ & $0.17^{b}$ & -0.07 & 0.02 & 0.07 & -0.09 \\
\hline Turkey & 0.01 & $4.24^{\mathrm{b}}$ & 1.95 & 832.23 & 0.00 & 0.12 & 0.98 & 0.00 & -0.98 & 0.00 \\
\hline Taiwan & 0.05 & $6.87^{\mathrm{b}}$ & 1.96 & 11.65 & 0.00 & $0.12^{b}$ & $-0.07^{\mathrm{a}}$ & 0.02 & $0.06^{\mathrm{a}}$ & $0.21^{\mathrm{b}}$ \\
\hline UK & 0.04 & $5.07^{\mathrm{b}}$ & 1.98 & 6.46 & 0.00 & $0.09^{\mathrm{a}}$ & $2.27^{b}$ & $-0.43^{\mathrm{a}}$ & $-3.82^{b}$ & $0.45^{\mathrm{a}}$ \\
\hline US & 0.07 & $8.45^{\mathrm{b}}$ & 1.99 & 6.48 & $0.00^{\mathrm{a}}$ & $0.08^{\mathrm{a}}$ & -0.67 & -0.08 & $-2.40^{\mathrm{a}}$ & 0.00 \\
\hline Vietnam & 0.12 & $9.29^{b}$ & 1.94 & 31.78 & 0.00 & $0.34^{\mathrm{b}}$ & -0.94 & 0.92 & 0.87 & -1.00 \\
\hline South Africa & 0.01 & $2.38^{\mathrm{a}}$ & 1.97 & 6.42 & 0.00 & $0.09^{\mathrm{a}}$ & 0.83 & 0.10 & -0.35 & -0.01 \\
\hline
\end{tabular}

${ }^{a}$ means significance with $10 \%$ confidential interval. ${ }^{\mathrm{b}}$ means significance with $1 \%$ confidential interval

The F-statistics of the 39 regressions are significant in the $10 \%$ confidential interval. Therefore, there is no significant auto-correlation in the error series of these regressions. In addition, it should be noted that VIF factors are smaller than 10 in most of the 39 regressions, except the models for Mexico, Russia and Turkey, because the 
financial markets are less efficient in these three emerging countries. For most countries, however, the estimations in the regressions are remarkable and reliable.

From most of the estimated results from Formula (2), the short-term government bond markets are positively correlated with stock markets in the same country during non-crisis periods. Furthermore, their interdependence becomes negative for most of the 39 countries during crisis periods, which is consistent with the definition of flight to quality. Unlike the short-term government bond markets, the long-term government bond markets are negatively correlated with the stock markets. This pattern is more significant for developed markets; however, the interdependence between the stock markets and the long-term government bond markets becomes positive for most countries during crisis periods. This is noteworthy, since the Subprime Crisis and the European Debt Crisis are not only financial crises, but also economic crises. Once a depression appears, the quality of the long-term government bonds will be more affected than the short-term government bonds because short-term government bonds are more liquid. The performance of the developed American market is different from most of the other regions. The short-term and the long-term government bond markets are both negatively dependent on the stock markets, since America dominates the market and its government bonds are regarded as the country's least risky financial asset, even though the U.S. was the source of the U.S. subprime mortgage crisis. Therefore, some investments flow into the U.S. government bond market from the stock market as a result of risk aversion.

Based on the definitions in the List of Tables:

Table 1: the characteristics of different types of interdependence are summarized in Table 5 and Fig. 1. There is neither a flight from quality (FFQ) nor positive spillover (PS) shown in Table 6, which proves that Hypothesis 2 is true.

To make different region's markets more comparable, the number of the countries is standardized by dividing the total sample number in different regions. The flight to quality occurs from the stock markets to the long-term and short-term government bond markets in a majority of selected developed countries. However, regarding the emerging markets, in Asian countries the flight to quality only occurs between the stock markets and the long-term markets. Furthermore, in emerging European counties and a few developed European countries (i.e., Italy and Greece), regardless of whether the market is developed

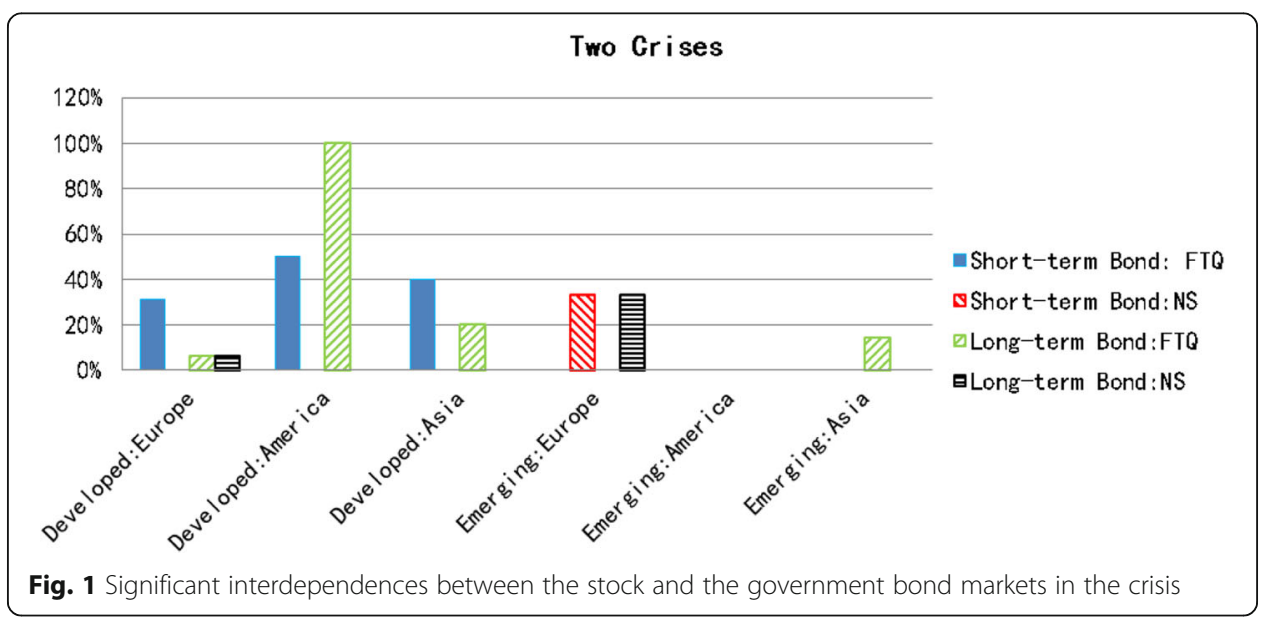


Table 6 Statistics to the results of Formula 2

\begin{tabular}{|c|c|c|c|c|c|c|c|c|}
\hline \multirow[t]{2}{*}{ Regions } & $\begin{array}{l}\text { Short-term } \\
\text { Bond }\end{array}$ & $\begin{array}{l}\text { Short-term } \\
\text { Bond }\end{array}$ & $\begin{array}{l}\text { Short-term } \\
\text { Bond }\end{array}$ & $\begin{array}{l}\text { Short-term } \\
\text { Bond }\end{array}$ & $\begin{array}{l}\text { Short-term } \\
\text { Bond* Crisis } \\
\text { Dummy }\end{array}$ & $\begin{array}{l}\text { Short-term } \\
\text { Bond* Crisis } \\
\text { Dummy }\end{array}$ & $\begin{array}{l}\text { Short-term } \\
\text { Bond* Crisis } \\
\text { Dummy }\end{array}$ & $\begin{array}{l}\text { Short-term } \\
\text { Bond* Crisis } \\
\text { Dummy }\end{array}$ \\
\hline & Mean & Median & $\begin{array}{l}\text { Standard } \\
\text { Error }\end{array}$ & $\begin{array}{l}\text { Negative } \\
\text { Coefficient }\end{array}$ & Mean & Median & $\begin{array}{l}\text { Standard } \\
\text { Error }\end{array}$ & $\begin{array}{l}\text { Negative } \\
\text { Coefficient }\end{array}$ \\
\hline $\begin{array}{l}\text { Developed } \\
\text { America }\end{array}$ & -0.31 & -0.31 & 0.51 & $50 \%$ & -2.27 & -2.27 & 0.18 & $100 \%$ \\
\hline $\begin{array}{l}\text { Developed } \\
\text { Europe }\end{array}$ & 0.35 & 0.16 & 0.85 & $38 \%$ & -2.00 & -1.81 & 1.33 & $94 \%$ \\
\hline $\begin{array}{l}\text { Developed } \\
\text { Asia }\end{array}$ & 0.16 & 0.06 & 0.36 & $40 \%$ & -1.32 & -1.10 & 1.14 & $100 \%$ \\
\hline $\begin{array}{l}\text { Emerging } \\
\text { America }\end{array}$ & 0.90 & 0.35 & 1.43 & $25 \%$ & -0.78 & -0.35 & 1.27 & $75 \%$ \\
\hline $\begin{array}{l}\text { Emerging } \\
\text { Europe }\end{array}$ & 0.49 & 0.54 & 0.36 & $20 \%$ & -0.92 & -0.97 & 1.85 & $60 \%$ \\
\hline $\begin{array}{l}\text { Emerging } \\
\text { Asia }\end{array}$ & -1.00 & -0.07 & 2.65 & $71 \%$ & 1.26 & 0.06 & 3.13 & $29 \%$ \\
\hline $\begin{array}{l}\text { Developed } \\
\text { Market }\end{array}$ & 0.25 & 0.05 & 0.75 & $39 \%$ & -1.87 & -1.89 & 1.24 & $96 \%$ \\
\hline $\begin{array}{l}\text { Emerging } \\
\text { Markets }\end{array}$ & -0.06 & 0.20 & 2.00 & $44 \%$ & 0.07 & -0.06 & 2.52 & $50 \%$ \\
\hline All & 0.12 & 0.06 & 1.39 & $41 \%$ & -1.08 & -0.98 & 2.08 & $77 \%$ \\
\hline \multirow[t]{2}{*}{ Regions } & $\begin{array}{l}\text { Long-Term } \\
\text { Bond }\end{array}$ & $\begin{array}{l}\text { Long-Term } \\
\text { Bond }\end{array}$ & $\begin{array}{l}\text { Long-Term } \\
\text { Bond }\end{array}$ & $\begin{array}{l}\text { Long-Term } \\
\text { Bond }\end{array}$ & $\begin{array}{l}\text { Long-Term } \\
\text { Bond* Crisis } \\
\text { Dummy }\end{array}$ & $\begin{array}{l}\text { Long-Term } \\
\text { Bond* Crisis } \\
\text { Dummy }\end{array}$ & $\begin{array}{l}\text { Long-Term } \\
\text { Bond* Crisis } \\
\text { Dummy }\end{array}$ & $\begin{array}{l}\text { Long-Term } \\
\text { Bond* Crisis } \\
\text { Dummy }\end{array}$ \\
\hline & Mean & Median & $\begin{array}{l}\text { Standard } \\
\text { Error }\end{array}$ & $\begin{array}{l}\text { Negative } \\
\text { Coefficient }\end{array}$ & Mean & Median & $\begin{array}{l}\text { Standard } \\
\text { Error }\end{array}$ & $\begin{array}{l}\text { Negative } \\
\text { Coefficient }\end{array}$ \\
\hline $\begin{array}{l}\text { Developed } \\
\text { America }\end{array}$ & -0.05 & -0.05 & 0.04 & $100 \%$ & -0.02 & -0.02 & 0.03 & $100 \%$ \\
\hline $\begin{array}{l}\text { Developed } \\
\text { Europe }\end{array}$ & -0.24 & -0.20 & 0.25 & $81 \%$ & 0.18 & 0.17 & 0.28 & $19 \%$ \\
\hline $\begin{array}{l}\text { Developed } \\
\text { Asia }\end{array}$ & -0.14 & -0.11 & 0.26 & $60 \%$ & 0.23 & -0.03 & 0.65 & $60 \%$ \\
\hline $\begin{array}{l}\text { Emerging } \\
\text { America }\end{array}$ & 0.13 & 0.10 & 0.12 & $0 \%$ & -0.14 & -0.20 & 0.23 & $75 \%$ \\
\hline $\begin{array}{l}\text { Emerging } \\
\text { Europe }\end{array}$ & 0.04 & 0.01 & 0.13 & $40 \%$ & 0.02 & 0.00 & 0.20 & $40 \%$ \\
\hline $\begin{array}{l}\text { Emerging } \\
\text { Asia }\end{array}$ & 0.06 & 0.02 & 0.42 & $29 \%$ & -0.27 & -0.09 & 0.46 & $71 \%$ \\
\hline $\begin{array}{l}\text { Developed } \\
\text { Market }\end{array}$ & -0.20 & -0.18 & 0.25 & $78 \%$ & 0.18 & 0.13 & 0.37 & $35 \%$ \\
\hline $\begin{array}{l}\text { Emerging } \\
\text { Markets }\end{array}$ & 0.07 & 0.04 & 0.28 & $25 \%$ & -0.15 & -0.10 & 0.35 & $63 \%$ \\
\hline All & -0.09 & -0.08 & 0.29 & $56 \%$ & 0.04 & 0.05 & 0.39 & $46 \%$ \\
\hline
\end{tabular}

* refers to the multiple symbol between two explanatory variables, i.e. the item with * inside is an interaction term

or emerging, the negative spillover only happens between the stock markets and the government bond markets. The negative spillover in Europe suggests that the investors lost their confidence in the recovery and solvency of the European countries during the Subprime Crisis and the European Debt Crisis periods. In addition, there is no flight from quality or positive spillover in these two crises. To summarize, all the negative spillovers occurred between the stock markets and the long-term government bond markets while the flight to quality emerged between the stock markets and the short-term government bond markets. For example, the remarkable flight to quality between the stock market and the long-term government bond market appears in the American market because the 
U.S. government bond is considered to be the safest asset in times of crisis. The longterm government bonds are less liquid than the short-term government bonds, such that the flight to quality between the stock market and the short-term government bond markets is of great significance, which proves that Hypothesis 3 is true.

Furthermore, the implications of the above results were analyzed by comparing the CDX indices to the returns of the government bonds. The CDXis an index on Credit Default Swaps of the government bonds, which is publicized by the Markit Company. In addition, the CDS is a popular financial derivative that uses the potential as the bond. In the CDS transaction, the buyer pays payments periodically to the seller and gains the right to sell the underlying bond to the seller at par when default occurs. Thus, a higher CDS spread causes a higher CDX index, which indicates a higher possibility of default for the related bonds. The correlation between the changing rate of the CDXs and the returns of the government bonds is positive in most developed countries, but negative in emerging markets. This is especially true in countries with high sovereign risks, such as the emerging European markets and Latin America. The significantly negative correlation between the changing rate of the CDXs and the returns of the government bonds exists, which means that the government bond is not a choice for risk aversion in countries with high sovereign risks (Table 7). That is why, in times of financial crisis, these countries suffer from negative spillover instead of flight to quality between the local stock markets and the government bond markets.

Due to the implication from Beber et al. (Beber et al. 2009), the sharp changes in sovereign yield spreads is explained using differences in credit quality, though liquidity plays a non-trivial role, especially for low credit risk countries and during times of heightened market uncertainty. This result is similar to the above proof for Hypothesis 3. In addition, Beber et al. (Beber et al. 2009) suggests that the destination of large capital flows into the bond market is determined almost exclusively by liquidity. The above results supplement our studies (Table 8).

Table 7 Increasing Ratios of sovereign debts in the two crises

\begin{tabular}{|c|c|c|c|c|c|c|}
\hline$\overline{\text { Regions }}$ & $\begin{array}{l}\text { Mean of } \\
\text { increasing } \\
\text { in 2008-2009 }\end{array}$ & $\begin{array}{l}\text { Median of } \\
\text { increasing } \\
\text { in 2008-2009 }\end{array}$ & $\begin{array}{l}\text { Faster increasing } \\
\text { in 2008-2009 } \\
\text { than in 2006-2007 }\end{array}$ & $\begin{array}{l}\text { Mean of } \\
\text { increasing } \\
\text { in 2010-2011 }\end{array}$ & $\begin{array}{l}\text { Median of } \\
\text { increasing } \\
\text { in 2010-2011 }\end{array}$ & $\begin{array}{l}\text { Faster increasing } \\
\text { in } 2010-2011 \\
\text { than in 2006-2007 }\end{array}$ \\
\hline $\begin{array}{l}\text { Developed } \\
\text { America }\end{array}$ & $6.7 \%$ & $6.7 \%$ & $100 \%$ & $10.2 \%$ & $10.2 \%$ & $100 \%$ \\
\hline $\begin{array}{l}\text { Developed } \\
\text { Europe }\end{array}$ & $8.7 \%$ & $8.3 \%$ & $88 \%$ & $8.5 \%$ & $7.6 \%$ & $94 \%$ \\
\hline $\begin{array}{l}\text { Developed } \\
\text { Asia }\end{array}$ & $12.8 \%$ & $8.7 \%$ & $60 \%$ & $19.4 \%$ & $8.4 \%$ & $80 \%$ \\
\hline $\begin{array}{l}\text { Emerging } \\
\text { America }\end{array}$ & $4.6 \%$ & $11.3 \%$ & $33 \%$ & $18.1 \%$ & $11.4 \%$ & $67 \%$ \\
\hline $\begin{array}{l}\text { Emerging } \\
\text { Europe }\end{array}$ & $9.7 \%$ & $10.8 \%$ & $100 \%$ & $31.6 \%$ & $28.6 \%$ & $100 \%$ \\
\hline Emerging Asia & $13.4 \%$ & $10.5 \%$ & $100 \%$ & $21.0 \%$ & $23.2 \%$ & $100 \%$ \\
\hline $\begin{array}{l}\text { Developed } \\
\text { Market }\end{array}$ & $9.4 \%$ & $8.7 \%$ & $83 \%$ & $11.0 \%$ & $8.4 \%$ & $91 \%$ \\
\hline $\begin{array}{l}\text { Emerging } \\
\text { Markets }\end{array}$ & $9.0 \%$ & $10.8 \%$ & $83 \%$ & $21.6 \%$ & $11.4 \%$ & $83 \%$ \\
\hline All & $9.0 \%$ & $9.4 \%$ & $81 \%$ & $14.4 \%$ & $10.6 \%$ & $89 \%$ \\
\hline
\end{tabular}


Table 8 Statistics to the different interdependences

\begin{tabular}{|c|c|c|c|c|c|c|c|c|}
\hline \multirow[t]{2}{*}{ Countries } & \multicolumn{2}{|l|}{ Two Crises } & \multicolumn{2}{|c|}{ US Subprime Crisis } & \multicolumn{2}{|c|}{ European Debt Crisis } & \multicolumn{2}{|c|}{ Robustness Test } \\
\hline & $\begin{array}{l}\text { Short-term } \\
\text { Bond }\end{array}$ & $\begin{array}{l}\text { Long-Term } \\
\text { Bond }\end{array}$ & $\begin{array}{l}\text { Short-term } \\
\text { Bond }\end{array}$ & $\begin{array}{l}\text { Long-Term } \\
\text { Bond }\end{array}$ & $\begin{array}{l}\text { Short-term } \\
\text { Bond }\end{array}$ & $\begin{array}{l}\text { Long-Term } \\
\text { Bond }\end{array}$ & $\begin{array}{l}\text { Short-term } \\
\text { Bond }\end{array}$ & $\begin{array}{l}\text { Long-Term } \\
\text { Bond }\end{array}$ \\
\hline \multicolumn{9}{|l|}{ Argentina } \\
\hline Austria & & FTQ & & FTQ & NS & FTQ & & \\
\hline \multicolumn{9}{|l|}{ Australia } \\
\hline Belgium & FTQ & & $\mathrm{FTQ}^{\mathrm{a}}$ & & & & FTQ & \\
\hline Brazil & & NS & & $\mathrm{NS}^{\mathrm{a}}$ & & & & NS \\
\hline Canada & & FTQ & & FTQ & & FTQ & $\mathrm{FTQ}^{\mathrm{a}}$ & FTQ \\
\hline Switzerland & $\mathrm{FTQ}^{\mathrm{a}}$ & & $\mathrm{FTQ}^{\mathrm{a}}$ & & $\mathrm{FTQ}^{\mathrm{a}}$ & FTQ & FTQ & \\
\hline \multicolumn{9}{|l|}{ Chile } \\
\hline China & & FTQ & & FTQ & & FTQ & & $\mathrm{FTQ}^{\mathrm{a}}$ \\
\hline \multicolumn{9}{|l|}{ Czech } \\
\hline Germany & & & & & & & $\mathrm{FTQ}^{\mathrm{a}}$ & \\
\hline Denmark & & & & & & & $\mathrm{FTQ}^{\mathrm{a}}$ & \\
\hline \multicolumn{9}{|l|}{ Spain } \\
\hline \multicolumn{9}{|l|}{ Finland } \\
\hline France & & & & & & FTQ & & \\
\hline Greece & & & & & & & FTQ & $N S^{a}$ \\
\hline Hungary & $N S^{a}$ & & $N S^{a}$ & & & NS & $\mathrm{NS}^{\mathrm{a}}$ & \\
\hline Indonesia & & & & & & & & $\mathrm{FTQ}^{\mathrm{a}}$ \\
\hline Ireland & & & & & & & NS & $\mathrm{FTQ}^{\mathrm{a}}$ \\
\hline Israel & FTQ & & FTQ & & FTQ & & & \\
\hline India & & & & & & & NS & $\mathrm{FTQ}^{\mathrm{a}}$ \\
\hline Italy & FTQ & NS & $\mathrm{FTQ}^{\mathrm{a}}$ & NS & & $N S^{a}$ & $\mathrm{FTQ}^{\mathrm{a}}$ & $N S^{a}$ \\
\hline Japan & & $\mathrm{FTQ}^{\mathrm{a}}$ & & & NS & $\mathrm{FTQ}^{\mathrm{a}}$ & NS & \\
\hline Korea & FTQ & & FTQ & & & FTQ & FTQ & NS \\
\hline Netherlands & $\mathrm{FTQ}^{\mathrm{a}}$ & & $\mathrm{FTQ}^{\mathrm{a}}$ & & $\mathrm{FTQ}^{\mathrm{a}}$ & FTQ & $\mathrm{FTQ}^{\mathrm{a}}$ & \\
\hline Norway & $\mathrm{FTQ}^{\mathrm{a}}$ & & FTQ & & $\mathrm{FTQ}^{\mathrm{a}}$ & NS & $\mathrm{FTQ}^{\mathrm{a}}$ & \\
\hline New Zealand & & & NS & & & & NS & \\
\hline Poland & & NS & & NS & & & & $\mathrm{NS}^{\mathrm{a}}$ \\
\hline Portugal & & & & FTQ & & & & $\mathrm{FTQ}^{\mathrm{a}}$ \\
\hline Sweden & & & & & & & $\mathrm{FTQ}^{\mathrm{a}}$ & \\
\hline Thailand & & & & & & & & FTQ \\
\hline Taiwan & & $N S^{a}$ & & $N S^{a}$ & & $N S^{a}$ & $\mathrm{FTQ}^{\mathrm{a}}$ & $N S^{a}$ \\
\hline \multicolumn{9}{|l|}{ UK } \\
\hline US & $\mathrm{FTQ}^{\mathrm{a}}$ & FTQ & $\mathrm{FTQ}^{\mathrm{a}}$ & & FTQ & FTQ & $\mathrm{FTQ}^{\mathrm{a}}$ & \\
\hline \multicolumn{9}{|l|}{ Vietnam } \\
\hline South Africa & & & & NS & & & NS & NS \\
\hline
\end{tabular}

'FTQ' stands for Flight to Quality while 'NQ' stands for Negative Spillover

${ }^{a}$ stands for significance in $10 \%$ confidential interval

\section{Different types of interdependence in the two latest crises}

This section examines different kinds of interdependence in the U.S. subprime mortgage crisis and the European Debt Crisis on the basis of Formula (3) (Table 9). This is similar to the previous section, which states the F-statistics are significant in the $10 \%$ confidential interval level for all the 39 regressions and there is no significant 
Table 9 Correlations between CDX and returns of government bonds

\begin{tabular}{lrrrlrrrr}
\hline Regions & Mean & Median & $\begin{array}{l}\text { Standard } \\
\text { Error }\end{array}$ & $\begin{array}{l}\text { Negative } \\
\text { Value }\end{array}$ & Mean & Median & $\begin{array}{l}\text { Standard } \\
\text { Error }\end{array}$ & $\begin{array}{l}\text { Negative } \\
\text { Value }\end{array}$ \\
\hline Developed America & 0.02 & 0.02 & 0.29 & $50 \%$ & 0.01 & 0.01 & 0.16 & $50 \%$ \\
Developed Europe & 0.06 & 0.27 & 0.42 & $38 \%$ & 0.03 & 0.12 & 0.36 & $44 \%$ \\
Developed Asia & 0.20 & 0.08 & 0.22 & $0 \%$ & 0.18 & 0.13 & 0.23 & $0 \%$ \\
Emerging America & -0.23 & -0.17 & 0.15 & $100 \%$ & -0.30 & -0.21 & 0.17 & $100 \%$ \\
Emerging Europe & -0.21 & -0.26 & 0.23 & $75 \%$ & -0.19 & -0.27 & 0.37 & $75 \%$ \\
Emerging Asia & -0.05 & -0.02 & 0.12 & $67 \%$ & 0.01 & 0.06 & 0.23 & $33 \%$ \\
Developed Market & 0.09 & 0.22 & 0.37 & $30 \%$ & 0.06 & 0.13 & 0.32 & $35 \%$ \\
Emerging Markets & -0.13 & -0.17 & 0.28 & $75 \%$ & -0.14 & -0.23 & 0.35 & $67 \%$ \\
All & -0.02 & 0.04 & 0.37 & $49 \%$ & -0.03 & 0.01 & 0.35 & $49 \%$ \\
\hline
\end{tabular}

autocorrelation for the errors of 39 regressions. In addition, the estimation of the 39 regressions is significant and reliable.

The interdependence between the stock markets and the government bond markets shows some similar patterns in the Subprime Crisis and the European Debt Crisis. During the Subprime Crisis the short-term government bond markets are negatively correlated with the stock markets in the same countries during the, which is consistent with the definition of flight to quality. However, the short-term government bond markets become positively correlated with the stock markets in certain developed European countries (i.e., Italy and Greece) and all emerging markets (Table 10), which shows that the flight to quality only occurs in developed countries, while negative spillover appears in the emerging markets and Europe's PIIGs countries, which is consistent with Hypothesis 4.

Furthermore, this section focuses on different types of interdependence in the crisis periods. Figures 2 and 3 are both standardized as Fig. 1. In these two crises, the flight to quality between the stock markets and the short-term bond markets occurs more frequently in developed markets. However, in emerging Asian markets the flight to quality only occurs between the stock markets and the short-term government bond markets. However, the flight to quality occurred less frequently in the European Debt Crisis due to the worse quality of the European sovereign debts, which proves Hypothesis 5 is true. Additionally, the negative spillover also occurred more frequently during the Subprime Crisis than in the European Debt Crisis. However, during the European Debt Crisis, the negative spillover was more frequent between the stock markets and the long-term government bond markets in the European and Asian developed markets. The developed European countries that suffered from negative spillover during the two crises are the PIIGs countries, Greece and Italy in particular. To summarize, the above analysis proved that both the flight to quality and the negative spillover occur more frequently in the very beginning of the crisis. Additionally, the countries that suffered more from the crisis (such as the PIIGS countries) will also experience more frequent negative spillovers in the government bond markets and the stock markets. Similar to the conclusion drawn in the previous section, the developed American markets always have significant flight to quality since the U.S. government bond is regarded as the safest asset during times of crisis.

To show more evidence in the above conclusion, the above results of interdependence are compared with the sovereign debt in the related countries. For the purposes 


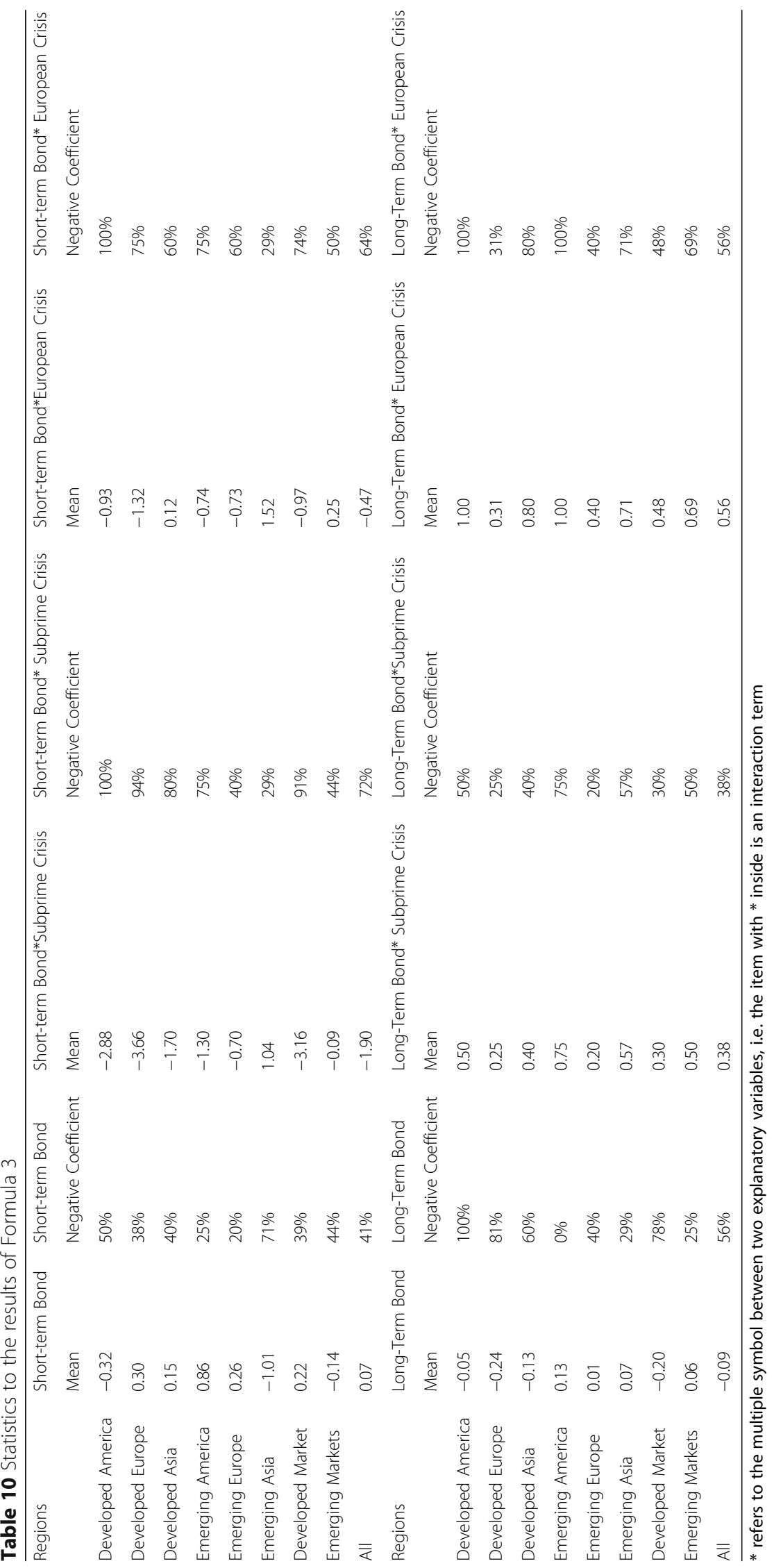




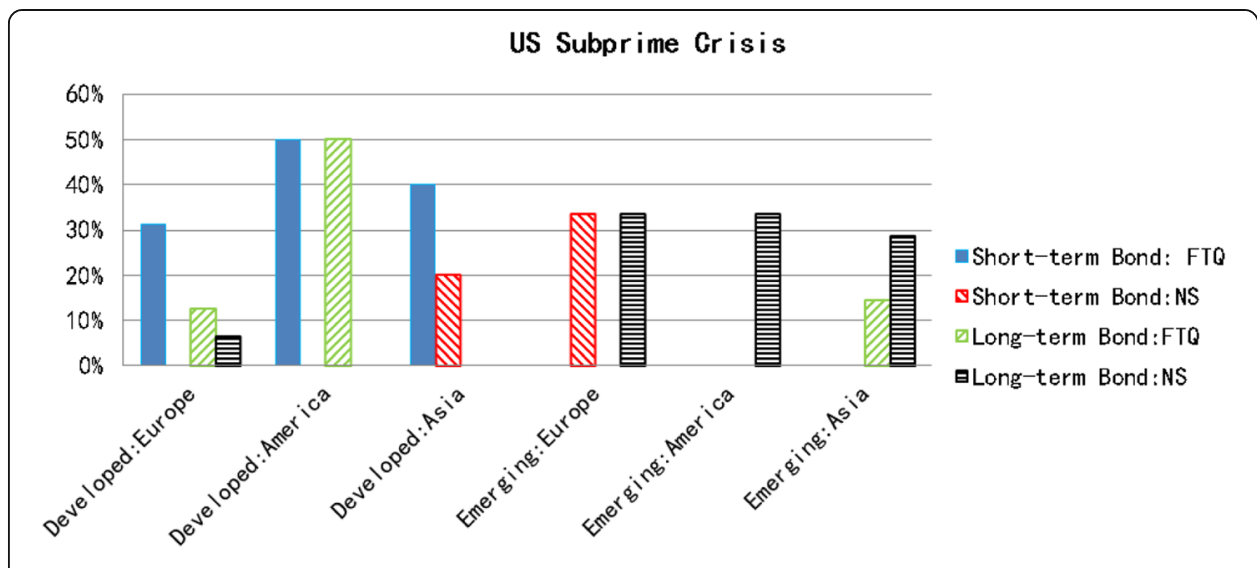

Fig. 2 Significant interdependences between the stock and the government bond markets in US Subprime crisis

of this paper, we consider 2008 to 2009 as the period of the Subprime Crisis while 2009 to 2011 is regarded as the European Debt Crisis period. For purposes of comparison, the years between 2006-2007 have been chosen as the non-crisis period. The sovereign debts increased in all the emerging market countries during the two crises, but especially during the European Debt Crisis. Therefore, in emerging markets government bonds are more illiquid and risky than bonds in developed markets. Therefore, negative spillover occurs more frequently than flight to quality in these emerging markets. Once the European Debt Crisis worsened and had a greater effect on Europe's developed countries, the flight to quality also appeared less frequently in those developed countries. Different kinds of interdependence implicate the different quality of sovereign debts in both the developed and emerging markets.

\section{Robustness tests}

To conduct the robustness test, Formula (2) is reestimated by defining the crisis period with the crisis status in the Markov-switching Regression [Formula (1)].

In the robustness test, the crisis period is defined using data and statistics instead of the pre-decided definition, which makes the estimation of Formula (2) more significant.

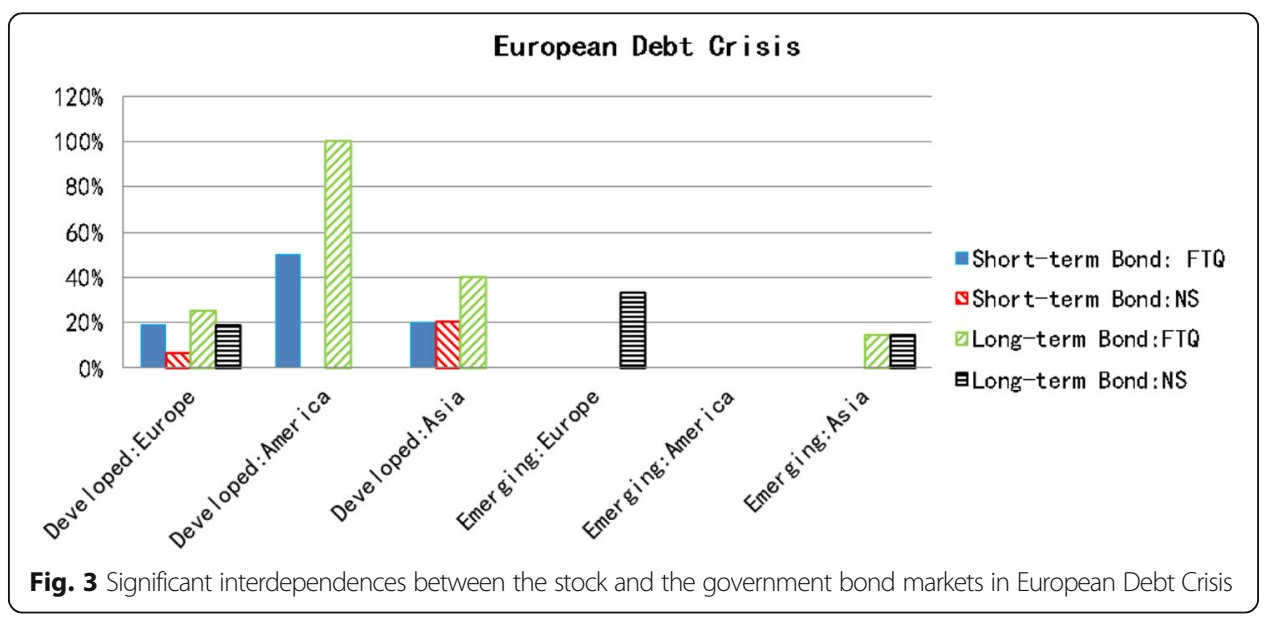


In addition, the directions of the coefficients are consistent with the previous results. To be specific, in most of the developed markets, the flight to quality occurred between the stock markets and the short-term government bond markets. However, in the emerging markets, there was little flight to quality evident between the stock markets and the short-term government bond markets. In certain emerging Asian markets, the flight to quality was seldom evident between the stock markets and the long-term government bond markets. Second, with the exception of the developed American market, there is significant negative spillover between the stock markets and the long-term government bond markets. This is in line with the previous conclusions.

\section{Conclusion}

This work investigated different types of interdependence between the stock and the government bond markets in the same country, and special patterns of interdependence during the Subprime Crisis period and the European Debt Crisis period were summarized. In this paper, we suggest that risk aversion becomes the main cause of investment flowing across different regions during times of financial crisis. Once the financial crisis occurs, most investors prefer bonds to stocks because, in the same region, stock markets are riskier than the government bonds. This is why neither the flight from quality nor the positive negative occurs during times of crisis. Furthermore, investors tend to choose safer markets based on their judgment of the safe haven. Generally speaking, the cash flows are more likely to occur in the government bond markets of developed countries. In particular, government bonds in the emerging markets and the long-term government bonds in the sovereign debt crisis are not deemed to be safe assets, so they do not attract investors during crises.

To be specific, we have concluded the following items for interdependence:

1. During non-crisis periods, the short-term government bond markets and the stock markets are positively interdependent in most countries. However, during crisis periods, their interdependence becomes negative and leads to flight to quality, since the government bond markets involve less risk and more funds may flow from the stock markets to the government bond markets for risk aversion.

2. Compared with the short-term government bond market, a long-term government bond market is rarely dependent on the stock market in the same country because it is significantly correlated with the long-term trend of the local economy. During the crisis period, the interdependence between these two markets remains negative, especially for the countries with a higher sovereign debt risk.

3. During times of crisis, the flight to quality is more popular than the negative spillover between the stock markets and the government bond markets in developed countries. The negative spillover often occurs in the emerging markets as well as the PIIGS countries, which are developed European countries but ones that suffer from the high sovereign risk during crisis periods.

4. The flight to quality or negative spillover occurs more frequently at the beginning of a crisis. The developed American markets always witness significant flight to quality since the U.S. government bond is considered to be the safest asset during times of crisis. 
Furthermore, this paper presents two implications for risk management. To be specific, it is first important to measure the quality gap between different assets in the same country. Timely monitoring with concern to the quality gap between different assets would be beneficial to risk management regarding uncertain cash flow across different financial markets. Secondly, the government should keep the policy stable to provide international investors more confidence in local financial markets, since having more faith in governmental policy would reduce the magnitude and destructiveness of the international cash flow.

\section{Acknowledgement}

This paper is funded by China Postdoctoral Science Foundation (2014M550985) and National Science Foundation of China $(71532013,71528001)$

\section{Authors' contributions}

$\mathrm{KC}$, carried out the data arrangement, conceived of the study, performed the statistical analysis and drafted the manuscript. XY, participated in the design of the study and helped to draft the manuscript. Both authors read and approved the final manuscript.

\section{Competing interests}

None of the authors have any competing interests in the manuscript.

\section{Publisher's Note}

Springer Nature remains neutral with regard to jurisdictional claims in published maps and institutional affiliations.

\section{Author details}

${ }^{1}$ China University of Petroleum, Beijing 102249, People's Republic of China. ${ }^{2}$ Academy of Mathematics and Systems Sciences, China's Academy of Sciences, Beijing 100190, People's Republic of China.

Received: 27 October 2015 Accepted: 16 March 2017

Published online: 09 April 2017

\section{References}

Aslanidisa N, Christiansen C (2012) Smooth transition patterns in the realized stock-bond correlation [J]. J Empir Financ 19(4):454-464

Baur D, Lucey B (2009) Flights and contagion - an empirical analysis of stock-bond correlations [J]. J Financ Stab 5(4):339-352

Beber A, Brandt MW, Kavajecz KA (2009) Flight-to-quality or flight-to-liquidity? evidence from the euro-area bond market [J]. Rev Financ Stud 22(3):925-957

Brièrea M, Chapelle A, Szafarz A (2012) No contagion, only globalization and flight to quality [J]. J Int Money Financ 31(6):1729-1744

Bernanke B, Gertler M, Gilchrist S (1996) The financial accelerator and the flight to quality [J]. Rev Econ Stat 78(1):1-15

Caballero RJ, Krishnamurthy A (2008) Collective risk management in a flight to quality episode [J]. J Financ 63(5):2195-2230

Chan K, Treepongkarunab S, Brooksc R, Gray S (2011) Asset market linkages: Evidence From financial, commodity and real estate assets [J]. J Bank Financ 35(6):1415-1426

Cheng K, Lu F, Yang X (2011) Copula contagion index and its efficiency. Appl Financ Econ 22(12):989-1002

Forbes KJ, Rigobon R (2002) No contagion, only interdependence - measuring stock market comovements [J]. J Financ 57(5):2223-2261

Gulko L (2002) De-coupling [J]. J Portfolio Manage 28(3):59-66

Hamilton J (1989) A new approach to the economic analysis of nonstationary time series and the business cycles [J]. Econometrica 57:357-384

Krolzig H (2004) Constructing turning point chronologies with Markov-switching vector autoregressive models: the euro-zone business cycle[M]. Eurostat Colloq on Mod Tools Bus Cycle Analy. 1:147-190.

Lang WW, Nakamura LI (1995) Flight to quality in banking and economic activity [J]. J Monet Econ 36(1):145-164

Vayanos D (2004) Flight to quality, flight to liquidity, and the pricing of risk [R]. National Bureau of Economic Research (No. w10327). http://www.nber.org/papers/w10327 